\title{
CRITICAL ANALYSIS OF IAS 2 ,STOCKS”, VERSION OF 2005
}

\author{
Mircea UNTARU \\ Romanian Academy, Bucharest, Romania \\ E-mail: mircea.untaru@andestm.ro
}

\begin{abstract}
This research paper aims to achieving a comparative analysis of the two versions of IAS 2 ,Stocks” (variants of 1993 and 2005). The research is part of a larger study regarding the accounting processes carried out for the acknowledgement and assessment of the company stock, and the purpose of the study is to develop a new framework methodology for the acknowledgement and assessment of stocks.

The research is based on a series of work hypotheses: (I1) IAS 2 variant of 1993 needs to be reviewed according to the regulations and normatives in force; (I2) the necessity to review IAS variant of 1993 derives from the critics raised by the regulating authorities for stock and shares, by the professional accountants and by other interested parties, with regard to the reduction or elimination of alternatives, redundancies and conflicts from standards, and the solving of convergence issues; (I3) the 2005 variant of IAS 2 is the result of a limited reviewing of the 1993 variant of IAS 2, and needs to be further modified.
\end{abstract}

Keywords: IAS 2 „Stocks”, critical and comparative analysis, the International Accounting Standard, stock assessment

JEL Classification: $\mathrm{M}_{41}$

\section{Introduction}

The history of IAS 2 started with its first issuing in 1974, its endorsement coming one year later, in October 1975, under the name of IAS 2 ,Evaluation and presentation of stocks within the context of the historic cost system".

In 1993, the Committee for International Accounting Standards modified the IAS 2 standard and published it in December 1993, under the name of IAS 2 „Stocks”. The first signal for the modification of IAS 2 „Stock” occurred in 1999, through the elaboration of SIC 1 „Consistency - Various methods for the determination of stocks costs".

In 2003, the International Accounting Standard IAS 2 „Stocks” suffered some minor alterations, more in its essence than in its form, and the result was the current standard, which came into force in January 2005.

The fundamental objective of the IAS 2 ,Stocks" is to offer the legal framework for the description of the accounting treatment of stocks. The specialised literature emphasises the existence of a fundamental issue in stock 
accounting, namely the value of the cost that is to be recognised as asset and reported until the acknowledgement of the relevant income. IAS 2 "Stocks" provides for recommendations related to the determination of the cost and to its consequent acknowledgement as expense, including any reduction of the value down to the net achievable value. Moreover, the standard provides for recommendations related to the formulae for the determination of the cost, used for the calculation of stocks costs. (CECCAR, 2013)

The problematic of stocks accounting has been widely approached in the specialized literature. (Carl S.Warren, James Reeve, \& Jonathan Duchac, 2013), (Ristea, M., \& Dumitru, C., 2007), (Ristea, M., 2005), (Ristea, M., \& Dumitru, C., 2003), (Needles, B.E., Anderson, J.R., \& Caldwell, J.C., 2000), (Feleaga, N., \& Ionaşcu, I., 1998).

Definitions given in such literature with regard to stocks all boil down to the same conclusion, namely that stocks represent the entirety of goods that intervene in the operation cycle, either intended to be sold under the same form (merchandise) or at the end of the production process (finished products), or to be consumed during the first exploitation. Stocks are included in the category of floating assets, and they classify as floating assets when they are being purchased, or as products for own consumption or products intended for selling, and they are expected to be achieved within 12 months from the date of the balance sheet. The characteristic of stocks is that they are consumed from the first exploitation, and they fully transfer their value on the achieved products. (Bradu, I., 2010)

The accounting of stocks is a modern issue of great interest for many entities, due to its significance with regard to the financial position and performance. Mainly, Stocks Accounting should be regarded with interest and responsibility by two categories of entities, namely: (Morariu, A., 2012)

a) the distribution entity (trader), meaning a retailer or a wholesale agent that has a single stock account - the merchandise stock (goods at their disposition, which they have purchased in order to re-sell);

b) the manufacturer, that ordinarily has three categories of stocks: raw materials, products in course of execution, and finished products.

Therefore, we may observe that the IAS 2 "Stocks" standard applies to the following categories of stocks, designated as floating assets by OMFP 3055/2009: (http://codfiscal.net)

a) stocks held in order to be sold, along the ordinary development of the company activity;

b) stocks in the production process, in view to be sold along the ordinary development of the company activity;

c) stocks in the form of raw materials, materials and other consumables that are to be used in the production process or for services supply.

In order to evaluate the assets of a company, there are several methods recommended by the international standards:

1. Evaluation in terms of cost history. By this method, assets are registered in terms of cash or cash equivalents paid upon purchase or in terms of the right value of the amount paid upon purchase. Debts are registered in terms of the equivalents 
obtained in exchange for the bond, or, under certain circumstances, in terms of the amount that is to be paid in cash or cash equivalents in order to extinguish the debt, during the normal development of the company activity.

2. Evaluation of stocks in terms of current cost. The use of such method implies that assets are registered in terms of the amount in cash or cash equivalents that should be paid if the said asset or a similar asset were currently purchased.

Debts are registered in terms of the non-updated value of the amount in cash or cash equivalents necessary in order to currently extinguish the bond.

3. Evaluation of stocks in terms of the achievable value (of discount). Assets are registered in terms of the amount in cash or cash equivalents that may be obtained currently by normally selling the assets.

Debts are registered in terms of their discount value, respectively of the nonupdated value in cash or cash equivalents that should be paid in order to extinguish the debts, during the normal development of the company activity.

4. Evaluation of stocks in terms of updated value. Such method implies that assets are registered in terms of the updated value of future net income in cash that is to be generated along the normal development of the company activities.

The general framework of International Accounting Standards states, in paragraph 101, that the evaluation base most frequently adopted by entities while assessing financial situations is the cost history method. It is commonly combined with other evaluation bases, as, for example:

- stocks, which are usually registered in terms of the lesser between the cost and the net achievable value;

- transactionable titles - in terms of the market value;

- debts regarding pensions - in terms of their updated value.

Certain entities use the current cost as an answer to the lack of capacity of the accounting model based on the cost history to solve problems related to the effect of the modification of non-cash assets prices.

The issue of interest is the stock assessment base.

According to the Accounting Standards, the base for the evaluation of stocks remains the "cost history", combined with the "net achievable value", in the form of the selection of "the lesser value between the cost of stocks and the net achievable value thereof".

\section{Description of the problem}

Within the process of stock evaluation, a significant issue, both from the theoretical - methodological point of view and the practical one, is the establishment of the procedure applied for the accurate determination of the stock cost, of the net achievable value, as well as the application of such procedures to the accounting works and the works for the drafting of financial reports. Given the importance of the assessment of stocks in view to drafting and presenting financial reports, our research focuses on the problematics of evaluation. 
The International Accounting Standard IAS 2 "Stocks" sums up a series of main characteristics and offers the legal framework for several activities related to the evaluation of stocks: (Florentin, D., 2013)

- possibilities of recognition for current assets in stocks area;

- determination of the value of the cost related to a stock element;

- procedures for the determination of the stock costs in function of the moment of the initial acknowledgement, as well as the treatments applicable to the stock evaluation at the time of the exit thereof;

- report with regard to the value attached to the stocks at the time of the initial acknowledgement of the financial status, up to the time when the income generated by such stock are acknowledged.

The standard covers the presentation of stocks, in order to get acquainted to and to understand the accounting treatment of stocks, by applying the cost history system.

The latest update of the International Accounting Standard IAS 2 "Stocks" happened in 2003, and the current standard entered into force on January $1^{\text {st }}, 2005$. The latest update was limited; therefore there are many requests for further modifications of the standard, mostly by professional accountants.

This research paper operates a critical analysis of the modifications brought to the IAS 2 "Stocks" variant of 1993 that have led to the issuing of the current standard, in 2005. The paper also emphasizes the need to further modify the IAS 2 "Stocks" variant of 2005.

The reasons for the further reviewing of the International Accounting Standard IAS 2 "Stocks" are as follows [9]:

- such reviewing may reduce or eliminate certain alternatives and redundancies with regard to the stock evaluation;

- such reviewing may clarify the area of application in the sense that there are certain stocks that cannot be assessed by means of the IAS 2 standard, and there are certain stocks that enter the area of the standard application and qualify as exceptional only in terms of assessment.

The category of stocks that are not included in the application area comprise: plants, animals or harvested agricultural products, obtained from such plants and animals. Moreover, the International Standard excludes building contracts (IAS $11-$ Building Contracts) and the financial instruments (IAS 39), but the principles of the standard may apply to such categories, when "there is a decision regarding the manner of implementation of certain aspects of the excluded standards". (Greuning, H., Scott, D., \& Terblanche, S., 2011)

The IAS 2 "Stocks" version, which has applied since January $1^{\text {st }}$, 2005, comprises 42 paragraphs, with equal authority, as well as the Annex and the Baseground for Conclusions. The preamble to the standard emphasises that "IAS 2 must be read within the context of its objective and of the Baseground for Conclusions, of its Preamble to the International Standards for Financial Reporting and of the General Framework for the Developing and Presentation of Financial Reports, as well as of the IAS 8 "Accounting policies, modifications of accounting 
estimates and errors", which offers a baseground for the selection and the application of accounting policies in the absence of certain specific guides". (CECCAR, 2013)

In order to identify, in terms of concept and operations, the sense and the significance of the elements introduced by the latest version of the standard IAS 2 "Stocks", this research paper analyses the motivation of the amendments, as well as the contents and the utility thereof for the accounting treatment of stocks, and the development and presentation of financial reports.

This analysis has been developed also from the perspective of the provisions issued in the preamble to IAS 2, considering, for a start, that the objective of the Standard, namely "the description of the accounting treatment for stocks" focuses on issues like:

- the value of the stock that is to be acknowledged as asset and reported until the acknowledgement of the relevant income;

- the calculation of the cost and the subsequent acknowledgement as expense, including any reduction of such value down to the net achievable value;

- formulae for cost calculation that are to be used for the calculation of stock costs.

The comparative analysis of the current version (2005) and the previous version (1993) of the IAS 2 ,Stocks" standard emphasises the areas that have been intervened upon, as well as the newly introduced elements. Table 1 shows a synthesis and a comparative tableau of the main structures and elements that differentiate the 2005 and the 1993 versions of the International Accounting Standard IAS 2 ,Stocks”.

Table 1

Comparative tableau of the IAS 2 ,Stocks” standard variants of 1993 and 2005

\begin{tabular}{|c|c|c|c|}
\hline No. & $\begin{array}{l}\text { Domain/ } \\
\text { Element }\end{array}$ & $\begin{array}{c}\text { IAS } 2 \text { "Stocks" } \\
\text { version } 1993 \\
\end{array}$ & $\begin{array}{c}\text { IAS } 2 \text { "Stocks" } \\
\text { version } 2005 \\
\end{array}$ \\
\hline 1. & Standard structure & Standard & $\begin{array}{l}\text { - Introduction } \\
\text { - Standard } \\
\text { - Annex } \\
\text { - Baseground for conclusions to } \\
\text { IAS } 2 \text { "Stocks" }\end{array}$ \\
\hline 2. & $\begin{array}{l}\text { Number of } \\
\text { paragraphs }\end{array}$ & 41 paragraphs & $\begin{array}{l}-17 \text { paragraphs, Introduction } \\
-42 \text { paragraphs, Standard } \\
-2 \text { paragraphs, Annex } \\
-23 \text { paragraphs, Baseground for } \\
\text { conclusions }\end{array}$ \\
\hline 3. & Introduction & & $\begin{array}{l}\text { - motivation for IAS } 2 \text { "Stocks" } \\
\text { revision } \\
\text { - main changes }\end{array}$ \\
\hline
\end{tabular}




\begin{tabular}{|c|c|c|c|}
\hline No. & $\begin{array}{l}\text { Domain/ } \\
\text { Element }\end{array}$ & $\begin{array}{c}\text { IAS } 2 \text { "Stocks" } \\
\text { version } 1993\end{array}$ & $\begin{array}{c}\text { IAS } 2 \text { "Stocks" } \\
\text { version } 2005\end{array}$ \\
\hline 4. & Standard & & \\
\hline 4.1. & Definitions & $\begin{array}{l}\text { - Stocks } \\
\text { - Net achievable value }\end{array}$ & $\begin{array}{l}\text { - Stocks } \\
\text { - Net achievable value } \\
\text { - Real value }\end{array}$ \\
\hline 4.2 . & Purchase cost & $\begin{array}{l}\text { - Includes currency } \\
\text { variations }\end{array}$ & - Excludes currency variations \\
\hline 4.3. & $\begin{array}{l}\text { Formulae for cost } \\
\text { calculation }\end{array}$ & $\begin{array}{l}\text { Introduces two types of } \\
\text { accounting treatment: } \\
\text { - basic treatment; } \\
\text { - allowed alternative } \\
\text { treatment }\end{array}$ & $\begin{array}{l}\text { - Introduces one single type of } \\
\text { treatment, through the elimination } \\
\text { of the allowed alternative treatment. }\end{array}$ \\
\hline 4.4 . & $\begin{array}{l}\text { Acknowledgement } \\
\text { as expense }\end{array}$ & $\begin{array}{l}\text { Paragraph } 32 \text { "The } \\
\text { acknowledgement of } \\
\text { the sold stocks value as } \\
\text { expense leads to the } \\
\text { connection of the costs } \\
\text { to the income from } \\
\text { current activities" }\end{array}$ & $\begin{array}{l}\text { Paragraph } 32 \text { from the } 1993 \text { version } \\
\text { has been eliminated }\end{array}$ \\
\hline 4.5 . & $\begin{array}{l}\text { Presentation of } \\
\text { information in } \\
\text { financial reports }\end{array}$ & $\begin{array}{l}\text { - paragraph } 34 \\
\text { Financial reports will } \\
\text { present the following } \\
\text { information: } \\
\text { c) accounting value of } \\
\text { such stocks that have } \\
\text { been evaluated in } \\
\text { terms of net achievable } \\
\text { value. } \\
\\
\text { - paragraph } 36, \text { Stocks } \\
\text { Cost, calculated } \\
\text { through LIFO formula, } \\
\text { letter a) and letter b) } \\
\text { - paragraph } 37 . \\
\text { Financial reports will } \\
\text { present some of the } \\
\text { following information } \\
\text { (optional): }\end{array}$ & $\begin{array}{l}\text { - paragraph } 36 \\
\text { Financial reports will present the } \\
\text { following information: } \\
\text { - c) accounting value of such } \\
\text { stocks registered in terms of the } \\
\text { real value minus selling costs; } \\
\text { - d) stocks value acknowledged as } \\
\text { expense over the period; } \\
\text { - e) value of any reduction of the } \\
\text { stocks' value as expense over the } \\
\text { period, according to paragraph } 34 \text {; } \\
\text { - paragraph } 36 \text {, letter a) and letter } \\
\text { b), LIFO formula, has been } \\
\text { eliminated. } \\
\text { - The optional presentation of the } \\
\text { information in letter a) or b) has } \\
\text { been eliminated, while the } \\
\text { remaining request refer to the } \\
\text { information in letter a) stock cost }\end{array}$ \\
\hline
\end{tabular}




\begin{tabular}{|c|c|c|c|}
\hline No. & $\begin{array}{l}\text { Domain/ } \\
\text { Element }\end{array}$ & $\begin{array}{c}\text { IAS } 2 \text { "Stocks" } \\
\text { version } 1993 \\
\end{array}$ & $\begin{array}{c}\text { IAS } 2 \text { "Stocks" } \\
\text { version } 2005 \\
\end{array}$ \\
\hline & & $\begin{array}{l}\text { a) stock cost } \\
\text { acknowledged as } \\
\text { expense over the } \\
\text { period; } \\
\text { or } \\
\text { b) exploitation costs } \\
\text { related to the income } \\
\text { from current activities, } \\
\text { classified after their } \\
\text { nature and } \\
\text { acknowledged as } \\
\text { expense over the } \\
\text { period. }\end{array}$ & $\begin{array}{l}\text { acknowledged as expense over the } \\
\text { period (see paragraph } 36 \text { letter d) } \\
\text { stock value acknowledged as } \\
\text { expense over the period) }\end{array}$ \\
\hline 5. & Annex & - & Amendments to other provisions \\
\hline 6. & $\begin{array}{l}\text { Baseground for } \\
\text { conclusions to } \\
\text { IAS } 2 \text { "Stocks". }\end{array}$ & - & 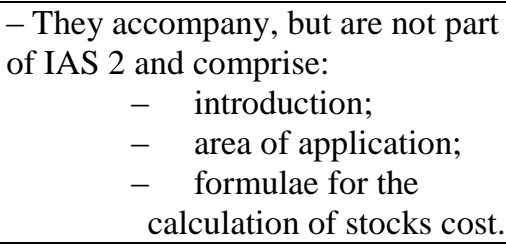 \\
\hline
\end{tabular}

Source: Created by the author, by use and interpretation of the two versions of IAS 2 "Stocks"

A first observation deriving from the comparative study of the two versions of IAS 2 "Stocks" standard is that the structure of the 2005 version is more complex, having an Introduction, the Annex and the Baseground for Conclusions. These new components of the IAS 2 "Stocks" standard accompany the proper standard, but are not part of the IAS 2 standard; nevertheless, this does not affect their utility.

The Introduction explains the reasons that have led to the revision of the Standard and emphasises the main changes that have been operated.

The Baseground for Conclusions presents the considerations and the arguments of the International Accounting Standards Board (IASB) that have been taken into account in order to issue revision decisions, based on the applicable professional reasons.

We appreciate that the two structures, the Introduction and the Baseground for Conclusions, are extremely useful for national accounting regulators, as well as for professional accountants, in order to understand the signification of the revisions and of the newly introduced elements, as well as the logic, the concepts and the reasons of the revised elements.

The Revision Motivation is the answer to the questions and critics raised by the regulating authorities for stocks and shares, by the professional accountants and 
by other interested parties, with regard to the reduction or the elimination of alternatives, redundancies and conflicts within standards, and to the treatment of certain convergence issues. It is a limited revision in view to the reduction of alternatives within the issue of stock assessment. The International Accounting Standards Board has not carried out a new analysis of the fundamental approach of stock accounting treated in IAS 2.

\section{Methodology and source of the data}

The research methods used in this paper have been: (1) critical analysis and (2) comparative analysis of the International Accounting Standard IAS 2 "Stocks", variants of 1993 and 2005. The bibliographic resources that have served as a baseground for the critic and comparative study of the research paper are the two versions of the IAS 2 standard, from 1993 and from 2005. (http://oferteconta.ro)

\section{Results obtained}

The main results of the critic and comparative analysis of the two versions from 1993 and 2005 of the International Accounting Standard IAS 2 "Stocks" refer to the revised aspects introduced in the 2005 version, as well as to the interpretation thereof:

1. Elimination of the phrase "held according to the cost history system" from the paragraphs that present the objective and the application area of the IAS 2 "Stocks" standard.

This amendment is explained in the "Baseground for Conclusions" in the sense that, given the fact that in the previous version both the objective and the area of application referred to "the accounting treatment of stocks according to the cost history system", some analysts have interpreted such phrase in the sense that the Standard only applies in accordance with the cost history system and that it allows entities to select the application of other evaluation bases, such as, for example, the real value. Since this has not been intended as the definition of the "cost history system", the Board has eliminated such phrase from the standard text, also by clarifying the fact that the Standard applies to all stocks that are not expressly excluded from its area of application.

\section{Clarification of the application area.}

In comparison with the previous version, the IAS 2 "Stocks" version of 2005 emphasises on two types of stocks, with regard to its area of application. This classification leads to the conclusion that, with regard to the accounting treatment of stocks, we may distinguish two types of stocks:

$>$ Types of stocks that are not within the area of application of the IAS 2 standard (paragraph 2, letter a), b) and c) also mentioned in the previous version);

$>$ Types of stocks that are exceptional only in terms of the evaluation of the requirements comprised in Standard 2 "Stocks" (paragraph 3, letters a and b). 
Therefore, there is a clear distinction between:

a. Stocks that are entirely outside the area of application of the Standard, described in paragraph 2, namely:

- production in process of execution within construction contracts and services thereof, that are covered by the area of application of IAS 11 "Construction contracts";

- financial instruments;

- biologic assets related to agricultural activities and to the agricultural production at the time of harvesting, assets that are covered by the area of application of IAS 41 "Agriculture";

b. Stocks that are outside the area of application of the evaluation requirements, but are covered by the area of application of other requirements of the Standard, described in paragraph 3.

In such cases, the Standard does not apply:

- to the evaluation of agricultural and forest related stocks that belong to producers, respectively agricultural production after harvesting and minerals and other mineral products, as long as they are evaluated in terms of the net achievable value according to well established practice within the activity sector (paragraph 3a);

- to the evaluation of stocks of stock exchange brokers, as long as they are evaluated in terms of the real value minus selling costs (paragraph $3 b$ ).

By examining the text of the Standard with regard to the area of application, one may notice that, in the case of Stocks that are entirely outside the area of application of the Standard, the reference is to categories, types of stocks, while, in the case of Stocks that are only outside the area of application of the evaluation requirements, but inside the area of application of other requirements of the Standard, the reference is to producers, respectively stock exchange brokers. We notice that the Standard allows for different treatments, mainly with regard to the holders of the stocks.

\section{Stock purchase costs}

3.1. The 2005 version of IAS 2 "Stocks" does no longer permit that the variations of currency that result directly from the recent purchase of stock invoiced in foreign currency be included in the purchase cost of stocks. This modification of the previous version of IAS 2 results from the elimination of the alternative treatment allowed for the capitalization of certain exchange differences present in IAS 21 "Effects of the currency exchange variations".

3.2. Paragraph 18 has been introduced with the purpose to clarify that, when stocks are purchased under delayed payment conditions, the differences between the purchase price for normal credit conditions and the amount paid should be acknowledged as interest expense in the structure of the purchase cost of stocks, over the financial period. 


\section{Formulae for cost calculation}

In order to better mark the requirements of the "Consistency" principle, the new version of the IAS 2 "Stocks" Standard includes the provisions of SIC 1 "Consistency - Various methods for stock cost calculation", in order for entities to use the same calculation formula for all stocks with similar nature and utility for such entity.

The 2005 IAS 2 version gives up the optional concept of accounting treatments for the evaluation of stocks (basic treatment and allowable alternative treatment), by introducing a single type of treatment, through the elimination of the allowable alternative treatment. This version of IAS 2 does no longer allow for the use of the LIFO (last in - first out) formula for the calculation of stock costs. Within the 13 paragraphs of the Baseground for Conclusions (BC9 to $\mathrm{BC} 21$ ), there are clear motivations and explanations with regard to the decision of the Board to eliminate the allowable alternative treatment, respectively the LIFO formula, with regard to the stock cost calculation. Here are some of these reasons:

- LIFO treats the newest parts of the stock as first sold (used), and, consequently, the parts that remain in stock are the oldest. Therefore, the LIFO method does not cover a credible representation of the real stock flows;

- the use of the LIFO formula results in stocks acknowledged in the balance as values that have little to do with the recent levels of stock costs.

Therefore, the Board has decided to eliminate the LIFO method, mainly because of its lack of representation of stock flows. Nevertheless, the Board mentions that this decision does not eliminate the specific methods of cost calculation, which reflect stock flows. Thus, IAS 2 "Stocks" still allows for the use of the FIFO method, as well as of the "balanced average cost" in terms of the calculation of the fungible stock costs.

With regard to the LIFO method, the Baseground for Conclusions underlines the acknowledgement by the Board of the fact that, in some jurisdictions, the use of such method for tax purposes is possible only if the method is used also for accounting purposes, and the conclusion has been drawn that the analyses regarding fiscality do not offer an appropriate conceptual baseground for the selection of an appropriate accounting treatment and that it is not acceptable to allow for an inferior accounting treatment only because of the fiscal regulations and advantages within such jurisdictions.

\section{Presentation of information in financial reports}

The schedule and structure of the information related to the stocks that are to be presented in financial reports have been extended in the 2005 version, in order to offer a more complete report to users. Thus, beside the information indicated in the 1993 version, the new version requires information such as:

a) the value of stocks registered in terms of the real value minus selling costs;

b) the value of stocks acknowledged as expense over the period;

c) the value of any reduction of the value of stocks as expense over the period. 


\section{Conclusions}

The critical and comparative analysis of the two versions of the IAS 2 "Stocks" standard of 1993 and 2005 confirms the hypotheses initially stated and that have formed the baseground of this research paper.

H1 The IAS 2 ,Stocks" variant of 1993 needs to be reviewed according to the regulations and normatives in force, given the fact that, in 1999, there have been certain modifications of the Standard by the introduction of SIC 1 - SIC 1 "Consistency - Various methods for stock cost calculation", in order for entities to use the same calculation formula for all stocks with similar nature and utility for such entity.

H2 The necessity to review IAS variant of 1993 derives from the critics raised by the regulating authorities for stock and shares, by the professional accountants and by other interested parties, with regard to the reduction or elimination of alternatives, redundancies and conflicts from standards, and to the solving of convergence issues.

H3 The 2005 variant of IAS 2 is the result of a limited reviewing of the 1993 variant of IAS 2, and needs to be further revised. The 2005 version of the IAS 2 "Stocks" maintains the previous principles and requirements regarding the acknowledgement and evaluation of stocks (cost history), with certain amendments with regard to the alternative treatments and the allowance for certain categories of entities to evaluate stocks in terms of the real value minus selling costs. Therefore, with regard to the evaluation of stocks in view to financial reports, paragraph 9 maintains the requirement that "Stocks should be evaluated in terms of the lesser value between the cost and the net achievable value".

In this view, paragraph IN3 from the Introduction specifies that „For IAS 2, the main objective of the Board has been to perform a limited revision, in view to reducing alternatives for the evaluation of stocks". The International Accounting Standards Board has not carried out a new analysis of the fundamental approach of stock accounting treated in IAS 2.

This work was supported by the project "Excellence academic routes in doctoral and postdoctoral research - READ" co-funded from the European Social Fund through the Development of Human Resources Operational Programme 2007-2013, contract no. POSDRU/159/1.5/S/137926.

\section{References}

Bradu, I. (2010), Politici şi tratamente contabile privind evaluarea stocurilor IAS 2, București.

Feleaga, N., \& Ionaşcu, I. (1998), Tratat de contabilitate financiară, vol. I si II, Bucureşti: Economică.

Florentin, D. (2013), Politici şi tratamente contabile privind evaluarea stocurilor IAS 2, Bucureşti.

Greuning, H., Scott, D., \& Terblanche, S. (2011), Standarde internationale de raportare financiară, Bucureşti: Institutul Irecson. 
MFP 3055/2009, Reglementări contabile conforme cu directivele europene, http://codfiscal.net/39020/mfp-modificarea-si-completarea-unor-reglementaricontabile-omfp-30552009-proiect-ordin.

Morariu, A. (2012), IAS 2 convergențe şi divergențe între IAS 2 şi norma națională (OMFP 3055/2009).

Needles, B.E., Anderson, J.R., \& Caldwell, J.C. (2000), Principiile de bază ale contabilității, ediția a cincea, Chişinău: Arc.

Nica Dumitru (coord.), Ionescu Cicilia, Dobrin Marinică, Balu Mariana, Ionescu Eduard, Predescu Iuliana (2007), Evaluarea întreprinderii, Bucureşti: Editura Fundaţiei România de Mâine.

Ristea, M., \& Dumitru, C. (2007), Tratamente contabile şi informaționale privind stocurile; Revista Gestiunea şi Contabilitatea Firmei.

Ristea, M. (2005), Contabilitate financiară, Bucureşti: Universitară.

Ristea, M., \& Dumitru, C. (2003), Contabilitate financiară, Bucureşti: Mărgăritar.

Standardul IAS 2 "Stocuri” varianta 2005, IFRS 2013, Bucureşti: CECCAR.

Standardul IAS 2 "Stocuri” varianta 1993, http://oferteconta.ro/index.php/documentatie/ category/4-ias?download=151:ias-standardul-international-de-contabilitate-ias-2

Warren Carl S., Reeve James, \& Duchac Jonathan (2013), Accounting, South Western Educ Pub. 